\title{
Going to the exclusive show: Exhibition strategies and moviegoing memories of Disney's animated feature films in Ghent (1937-1982)
}

European Journal of Cultural Studies 2016, Vol. 19(4) 403-418 (C) The Author(s) 2015 Reprints and permissions: sagepub.co.uk/journalsPermissions.nav DOI: $10.1177 / 1367549415592894$ ecs.sagepub.com

@SAGE

\author{
Lies Van de Vijver \\ Ghent University, Belgium
}

\begin{abstract}
This is a case study of the exploitation and experience of Disney's animated feature films from the 1930s to the 1980s in Ghent (Belgium). It is a historical study of programming practices and financial strategies which constructed childhood memories on watching Disney. The study is a contribution to a historical understanding of the implications of global distribution of film as cultural products and the counter pull of localism. Using a multi-method approach, the argument is made that the scarce screenings were strategically programmed to uplift the moviegoing experience into something out of the ordinary in everyday life. Programming and revenue data characterize the screenings as exclusive and generating high intakes. Consequently, the remembered screenings did not exhale an easy accessible social status nor an image of pervasiveness of popular childhood film, contradictory to conventional accounts of Disney's ubiquity in popular culture.
\end{abstract}

\section{Keywords}

Childhood cinemagoing, cinema memory, cultural globalization, film programming and box office, localism, New Cinema History, Walt Disney

\section{Introduction}

Thus, understanding Disney's global impact and significance is not simply a matter of documenting and analyzing the continuing expansion of its products in global markets. We also

Corresponding author:

Lies Van de Vijver, Ghent University, Korte Meer 11, B-9000 Gent, Belgium.

Email: Liesbeth.vandevijver@ugent.be 
need to understand more carefully the consumption or reception process and the audiences for these products.[...] Communication researchers have paid relatively little attention to the audiences for Disney products.

Janet Wasko (2001)

Over the past decade, film studies have taken socio-economic cultural issues and especially audiences into consideration with film production being no longer the comprehensive basis for a representative history of the medium (Aveyard and Moran, 2013; Chapman et al., 2007; Maltby et al., 2007, 2011). More attention has been given to film as a commodity and as a cultural practice, as questions of audiences, reception, film businesses, programming strategies and other non-textual dimensions of cinema have established a film studies field with multi-method approaches and theoretical maturity tackling the 'problem' of the empirical, as called upon by Robert C. Allen (2006). Research on film audiences has underscored their heterogeneity and the influence of the social, cultural and historical conditions in audiences' experiences such as region, class and ideology (Biltereyst et al., 2011). And thanks to this historical turn in film studies and scholarly attention to historical audiences, empirical research has been undertaken these last years to understand cinemagoing and film consumption by qualitative audience research (Christie, 2006; Higashi, 2004). If the main concern is consumerism, film products, and especially popular film such as the animated feature films of Walt Disney, are analyzed in terms of how they were consumed in historical everyday life by contextualizing these films through a bottom-up approach.

At the same time, there has been a boom in Disney studies, due to the proliferation and popularity of Disney (Wasko et al., 2001). There are three main research trends in Disney studies. First, studies of Disney content have employed interpretative textual analysis of the animated feature films with a focus on race, ideology, feminist or gender perspectives, psychoanalyses or cultural imperialism (Ayres, 2013; Barrier, 2007; Bell et al., 1995; Brode, 2004; Davis, 2006; Dorfman and Mattelart, 1975; Field, 1942; Giroux and Pollock, 2001; Ohmer, 1993; Rothschild, 2013; Stein, 2011). Unfortunately, this is also prompting some scholars to join in the fashionable sport of Disney bashing. Second, there is an abundance of literature on the commercial personality of Walt Disney and the Walt Disney Company and brand, its aesthetic and its technological importance to animation and production histories. Disney's academic importance also increased due to the political economy readings of the company, examining networks of power within and outside the Hollywood film industry (Smoodin, 1994; Wasko, 2001). Third, the influence of cultural studies directed film studies to understand the manner in which texts are embedded in the wider social histories of popular entertainment, consumption, domestic leisure and the public sphere (Crafton, 2013; Elsaesser, 2014; Sammond, 2005). Yet, contrary to the massive abundance of current literature on the effects of globalized Western media such as mediated Disney products on cultural identity, or even the omnipresent academic research on children and media (Jenkins, 1998), little attention has been given to the counter pull of localism, and especially the shortage of substantive empirical audience research for Disney products is bemoaned (Buckingham, 1997; Wasko et al., 2001). 
This contribution looks at how Disney's animated feature films have been released and run in a local market throughout its entire history, how they were making money and how this influenced a constructed cultural memory of Disney. By researching the distribution, exploitation and reception history of Disney's animated feature films, the article uses a triangulation of methods, which by the efforts of the New Cinema History research has now received more widespread acceptance as an efficient means of analyzing the social experience of cinema through non-textual means (Aveyard and Moran, 2013; Maltby et al., 2007, 2011). Combining methods from film economics and empirical audience research, the article takes on a more bottom-up approach on the 'Disneyfication' of the leisure culture. By analyzing a specific popular culture phenomenon and its role in society as a microhistory (Ginzberg, 1993), the article attempts to understand the construction of childhood cinema memories as an example of the local counter pull to conventional accounts of Disney's pervasiveness.

The research has a focus on the Flemish city of Ghent between 1937 and 1982. Flanders, the densely populated Northern region of Belgium, as a case is challenging; it had a vivid film exhibition scene with high attendance rates as well as a wide range of luxurious and less luxurious cinemas. Cinemagoing quickly became a popular habit. As one of the few countries without any form of obligatory film censorship, the country largely maintained a liberal film policy. Ghent is fueled by contradictory forces (pillarization versus commercialism, center neighborhoods versus lower class districts, etc.) which, when analyzed, can be exemplary of a non-Anglo-Saxon point of view within current distribution and exploitation studies (Biltereyst and Meers, 2014). The Ghent case is profoundly entwined with local cultural factors, such as language struggles, that have had a minor part in American cinema history but were significant to non-American cinema history. Mark Phillips (2001) points out that even if the Disney company modified presentations to appear locally, it did offer standardized products, identical to the original American format; this research does the empirical ground work on how these American products were 'appropriated' (Elsaesser, 2014) in order to advance the Disney scholarship and to answer the call for more research into the global reception of media products in light of the continuing expansion of media and communication companies (Wasko, 2001). By taking aboard a certain democratic understanding of the motives and pleasures of mass media users, this article attempts to pay more attention to the materiality and heterogeneity of film consumption practices and to understand how something as popular, widespread and apparently pervasive as Walt Disney's animated feature films has been released and received throughout its history in a local market, constructing a remembered image of the experience.

\section{Researching Disney's exhibition strategies and childhood memories}

Questions into the history of cinema and its audiences are answered by using an array of methods, such as statistical calculations, qualitative data, longitudinal databases, analyses using geographic information systems, document analysis and others, to shed light on particular dimensions of cinema. But a multi-method approach, whereby more than one 
method is brought to bear on a single research problem, is hardly ever used on one particular case. Three sets of inquiries have been conducted for watching Disney: (1) Where and how were the animated feature films screened? (2) What was the revenue for these screenings? And (3) did these influence the constructed memories of childhood cinemagoing? Taken on its own, each inquiry produces a story, and while each story may be informative in its own right, and even offer new knowledge, combining the three intakes provides a nuanced and integrated understanding of the remembered experience of Disney.

First, the films themselves were traced to contextualize the memories. Programming research was conducted using archival material to reconstruct the supply. Starting from the initial release of Snow White and the Seven Dwarfs (1937), all 24 full-length animated films were researched in the way they were released in the market up until the introduction of the first multiplex cinema in town. ${ }^{1}$ As social and cultural life was historically pillarized (meaning everyday life was ideologized as socialist, Catholic or other life structuring concepts), weekly film programming listings in the local newspapers could vary according to the ideological image of the cinemas in question, implying the use of several newspapers. Weekly listings of the films were catalogued using the local and national newspapers present in university newspaper archives. Out of 2500 weekly screenings, a database was constructed with categories defining the Disney screening: the film, the cinema, the hour of screening and additional information mentioned in the listings (such as language, double bills, etc.). As such, a complete and exhaustive longitudinal reconstruction of the circulation and thus exploitation policy of Disney's animated feature films led up to a historical trace of animated feature films in the various cinemas around town - a virtual map of visibility on single screens at the time.

Second, the money was traced. Archival research on material kept in the State Archives of Belgium (Company Archive Sofexim-Cinex 1932-1982/Gent/B13) has uncovered unique fragments of financial revenue data on Disney's animated feature films in Ghent. Although film historians recognize the importance of the economic value of film, only few work out empirical economic analyses of the film business. Robert Ray (1985) has noted that in the postwar period, there was a blatant discrepancy between the most commercially successful movies and those that have ultimately been seen as significant, because film history has been written almost in its entirety with deliberate distaste for the box office. The information from the ledgers containing various data on exhibition runs, ticket prices, gross income, copyright taxes, net income and attendance was collected in a database. This exceptional archival material offers an important financial comment on the researched programming strategies and enables the mapping out of patterns of popular cultural consumption.

Finally, the research concluded with the oral histories of elderly inhabitants of the city of Ghent remembering going to the movies, watching films and experiencing cinema. As Robert C. Allen (2011) puts it, 'oral histories ... exponentially increase the number and variety of available film histories; they implicitly contest both the empiricist objectification of film history and the epistemological authority of the interpretive analyst. They explode any notion of a master narrative'. The oral history component of this research aimed to analyze the importance of cinemagoing in a local community defined by class, language and a pillarized society by using qualitative in-depth interviews (Perks and 
Thomson, 2000). The respondents were found through an advertisement in the local newspapers, and a variety of ages, interests, education levels, leisure pastimes and so on was assured. Statistical representativeness of the respondents was not claimed, and a variety was required to cover the years under research. In total, 62 inhabitants of Ghent born between 1915 and 1965 were selected and interviewed regarding their moviegoing habits from the 1930s onwards. The semi-structured interviews did not focus on verifiable facts of the Disney screenings. A main focus of the interviews was childhood memories, without questioning the respondents explicitly about the screenings of the animated feature films of Disney. The interviews were fully transcribed and thematically analyzed using a coded tree analysis. The analysis answered questions regarding the treasured and often revisited Disney memories, the social meaning and image of the Disney screenings and the interconnectivity and locality of childhood memories and Disney.

\section{Screening Disney}

Previous research on the film exhibition structure in Ghent has proven that there were quite clear programming strategies developed over the years in the cinemas (Van de Vijver, 2012). The number of cinemas dropped from 34 in 1937 to only 11 in 1982. The circulation of film in the city was rather flexible because, among other things, the film exhibition sector was in general independent: There was virtually no vertical integration in the city, and the competition was only between the different cinema managements within - for international standards - quite a small city. ${ }^{2}$ The film exhibition structure is thus mainly geographically hierarchized. Most of the center cinemas were highly profiled based on their program; some center cinemas were known to program risqué French cinema (as was the case for the Savoy), German and Austrian sing-along (as was the case for the Plaza) or British espionage (as was the case for the Select). The district cinemas and suburb cinemas were less identifiable by program choice, but the film distribution did have a geographical flow from center to districts and then suburbs (Van de Vijver, 2012). Language was not at all insignificant in Ghent; French was used as a distinction mechanism by the higher social classes. In the 1930s, a cultural language war broke out, instigated by the 'dutchifying' of the University of Ghent. The atmosphere between the classes personified by the spoken language remained tense. As for the film sector, the American distributors in (mainly French speaking) Brussels did not favor redubbing the films that had already been dubbed in French in France. The language issues came to rest in the film sector once the smaller versions of subtitles were technically possible to appear in both languages in one frame (Van de Vijver and Biltereyst, 2010). This discussion begs the question of how exactly children's entertainment was positioned in this cultural situation, as the spoken or heard language in the cinemas was anything but trivial.

The programming of Disney's animated feature films was analyzed in three categories: the premieres, the runs and the holiday screenings. The opening of Disney's animated feature films in Ghent turned out to be quite explicitly defined in place and time. An analysis of the different openings tells us that during the first glorious years after the war, running a Disney animated feature film for the first time in Ghent was usually planned in March or April, or in December. But this last strategy didn't fully work out until the beginning of the 1960s, when Disney very purposefully started their Christmas 
programming with first runs and reruns starting during the week of Christmas. From this moment on, Disney seemed to be clearly linked to the Christmas holiday season, a strategy with parallel success in their television market (Wasko, 2001). The feature films in Ghent progressively started rerun screenings over the Easter and summer holidays. Screening Disney was strategically linked to the holidays and turned going to the movies into a non-habitual event. By the end of the 1970s, the Christmas premiere screenings moved up, starting in the first week of December, sponging off the Christmas screenings atmosphere.

When looking at the way Disney's animated feature films then moved through the distribution flow, a remarkable pattern of strategic scarcity emerges. Disney's animated feature films were listed in the newspapers under the heading 'For everyone'. Comparing the film titles in these child-friendly listings, some titles were screened much more often over the years, such as the numerous screenings of De Witte (Jan Vanderheyden; Belgium, 1934), Der Bettelstudent (Georg Jacoby; Germany, 1936), Where no Vultures Fly (Harry Watt; UK, 1951), The Greatest Show on Earth (Cecil B. DeMille; US, 1951) and Seven Hills of Rome (Roy Rowlan; US/Italy, 1957), not to mention the rather insistent programming of The Sound of Music (Robert Wise; US, 1965), anything with Louis de Funès or later on the Star Wars movies. Over a period of years, Disney's animated feature films were screened only 309 times for a full week, or 0.5 percent of all available screenings between 1938 and 1982. It is safe to say the Disney animated feature films were just not around that much.

After the premieres, the runs of Disney's animated films had a gradual, yet strong identifiable profiling. The 24 feature films went from long runs (up to 11 weeks) in diverse programming in 11 cinemas throughout the city, to screening for a very short time exclusively in only two city center cinemas. When looking at the diversity of the cinemas in which Disney's animated feature films were made available, we find 40 different cinemas, but only nine of these cinemas were center cinemas, and they did have 64 percent of the total number of screenings. So, contrary to the general run of movies in our town from center to district to suburban cinemas, Disney's animated feature films were a lot more present in the high profile center cinemas. This started quite early on with an average run of 6 weeks for The Three Caballeros (1944), Cinderella (1950), Peter Pan (US, 1953) and Lady and the Tramp (1955). Starting with Sleeping Beauty (1959), there is a clear shift in the chosen cinemas; the film ran for several weeks but ran exclusively in the Capitole cinema and its next-door second-run cinema Select. It is noteworthy that the Capitole was the most prestigious cinema in Ghent, promoting itself as a luxurious film palace for the higher social classes while conducting a strategy of spatial segregation through a differentiated price policy. This only true movie 'palace' in town, with extensive staff (see Figure 1), catered to a wide variety of audience segments, provided they complied with the social status of the cinema (Van de Vijver et al., 2015). Capitole had strong management behind it, the cinema company Sofexim-Cinex, and the success of the Disney screenings did not go unnoticed. To boost newly acquired first-run venue in the upcoming residential periphery of Ghent, the Disney screenings transported to the outskirts of town. Rex was clearly opened under the Disney strategy, as it was the only cinema that did parallel screenings with the Christmas screenings of Robin Hood (1973) at Capitole in 1974. When the cinema company opened their first 


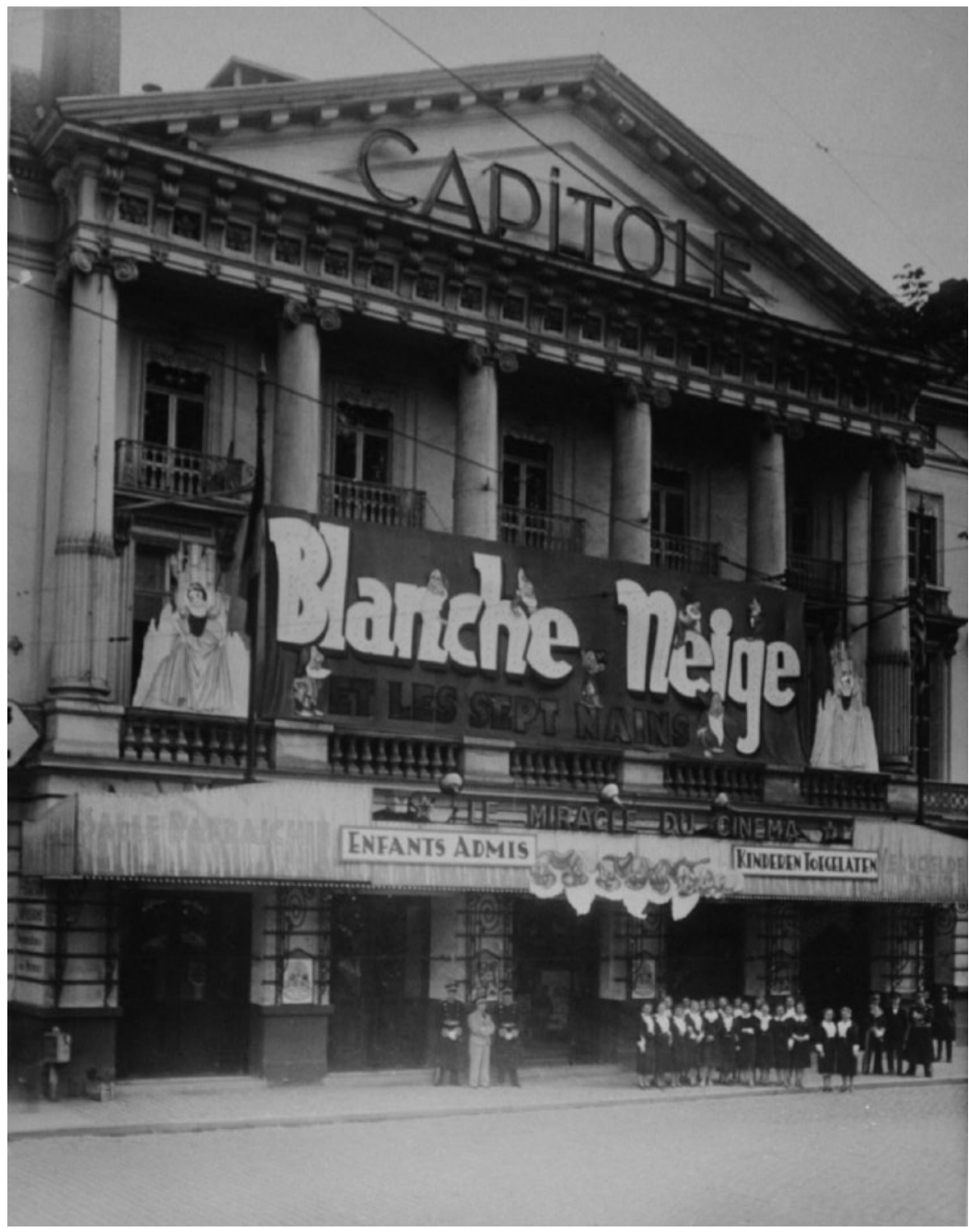

Figure 1. Capitole screening Blanche Neige et les sept nains ('Snow White and the Seven Dwarfs', William Cottrell, et al., Walt Disney Productions; US, 1937), undated. Source: Company Archive Sofexim-Cinex 1932-1982/Gent/B13/map754. Reproduced with the permission of the State Archives of Belgium.

duplex cinema in town, the Majestic, they did the only double screening of their Christmas movie by running Fantasia (1940) and Lady and the Tramp in the same week in 1976. But shifting the socially constructed experiences of Disney screenings because of economic reasons did not always work out; the Disney screenings were pulled from the outskirts in Rex and returned in second runs to Select. It is obvious that the screenings of Disney were geographically circumscribed to the square where Capitole and Select were located, backed by the habitual cinemagoing practices in town. 
As an example of the contradictory programming strategy in Ghent, international research concluded that Snow White and the Seven Dwarfs ran for nearly a year between 1938 and 1939. This turned the movie into a cultural event, as internationally the film broke all attendance records. This would imply, as Eric Smoodin (2012) suggested, that it constantly attracted new audiences and also that viewers went to see it again and again. The domestic exhibitors complained that the neighborhood and town folk left to see the cultural phenomenon in the city, disturbing the systematic logic of Hollywood distribution; additionally, the demands of Radio-Keith-Orpheum Pictures were too high. This could also be the case in Ghent, but in contrast to the demands on the domestic market, half of these screenings in Ghent of Snow White were double bills, and the traditional six period rereleases (Kuhn, 2010; Wasko, 2001) did not occur. Snow White seemed to succumb to locally specific stumbling blocks. First of all, the film was censored in Belgium in 1938, causing the local newspapers in Ghent to warn parents of horrific images. Second, this was the first animated film released in the midst of a cultural language war; the opening of the film on the 19th of August was advertised in Dutch, yet the billboards on the Capitole were in French, and the advertisements mentioned 'O.V.' ('original version' or 'subtitled version').

Even though it is clear that Disney was made into an exclusive event on religious holidays at the square where Capitole and Select were located, a final note needs to be said about Disney's presumed dominance of children's entertainment throughout December. Not all Christmases were 'Disneyfied', as the immensely popular French characters of Fernandel and Bourvil were also programmed, and the throne was on occasion shared with that other, at least for Belgians, world phenomenon, TinTin. And so the ubiquity and pervasiveness of Disney can be carefully questioned, as the programming analyses reveal carefully orchestrated holiday screenings at the luxurious flagship of the exhibition scene, constructing socially circumscribed cinemagoing practices. The programming analysis points to the importance of looking at screenings in a local context when considering that going to the cinema was not just a matter of seeing a movie; these cinemas were spaces associated with certain social classes, marked by their geographical location and a significant difference in programming strategies. This led to cinemagoing experiences of distinction as well (Van de Vijver and Biltereyst, 2013). Cashing in on Disney did not work through the traditional ways of the waterfall effect (from center to district to neighborhood), allowing as many people as possible to see the animated feature films on an accessible big screen. Disney was being held hostage at the one film palace in town and its second-run cinema next door, thoroughly confining the childhood film experience to a specific socio-culturally defined place of exclusivity.

\section{Cashing in on Disney}

The State Archives of Belgium preserved the business archive of the Sofexim-Cinex company responsible for a majority of the Disney screenings in Capitole. The archives contain ledgers with fragmented data regarding exhibition such as runs, tickets prices, revenue taxes and attendance, and so far, this is one of the few detailed extensive sources on attendance and revenue figures for one cinema. Unfortunately, as mentioned, the data are fragmented but can still shed light on the money made through Disney's animated 
feature films. Within economic film studies, financial data and programming data are used to identify community tastes and audience preferences, but this economic analysis is more put to use in understanding what Kate Bowles (2007) has termed 'the pragmatism of the market place'.

An analysis of the company archive of Sofexim-Cinex explains that its showpiece, Capitole, was not losing money (Van de Vijver et al., 2015). The early period of revenue data for the Disney screenings at Capitole are extremely fragmented. In 1947, the Walt Disney Company wasn't even mentioned in the revenue data. In 1953, Peter Pan (1953) was responsible for over 5 percent of the gross income of that year with 531,502 Belgian francs net income, as were Limelight (Charles Chaplin, Celebrated Productions; US, 1952) with 545,332 Belgian francs and The Crimson Pirate (Robert Siodmak; US, 1952) with 572,290 Belgian francs. But Moulin Rouge (John Huston; UK, 1952) hit the box office a lot harder that year, with 706,080 Belgian franc net income. Another piece of archival material gave us gross income, ticket prices, taxes paid, number of tickets sold and net income between 1953 and 1971 for all the screenings at the Capitole cinema, allowing a unique financial view regarding Disney's animated feature films compared to the regular program. For these years, 82 percent of all screenings ran for just one week. The Capitole had an average of 21 screenings per week, receiving an average weekly income of 189,000 Belgian francs for 6700 tickets. During this period, there were only two truly runaway hits, with over 20,000 admissions in 1 week, and one of them was a Walt Disney Production, The Aristocats (1970) in 1971. But the runaway hits based on weekly income (instead of attendance) show an exceptionally straightforward image of the Capitole. Eight of the top 10 films are productions by Walt Disney Productions, including two reruns. Only La Grande Vadrouille (Gérard Oury; France/UK, 1966, bringing in 601,030 Belgian francs), with the ever popular Louis de Funès and Bourvil, and The Longest Day (Kan Annakin, et al.; US, 1962, bringing in 547,005 Belgian francs) could make a small variation here, but both do not even scratch the surface of the massive income of 1,136,333 Belgian francs generated by The Aristocats. Yet, over the course of the years, Capitole did not raise its prices for Walt Disney Productions as a general strategy; the ticket price was always around the average, so this cannot be the explanation for the financial success of the screenings. Nor were the taxes, copyrights and royalties particularly high, as for these screenings the net income was well above average, as well for Capitole. In 1973, Snow White and the Seven Dwarfs did not have the longest run; the longest run was Last Tango in Paris (Bernardo Bertolucci; France/ Italy, 1972), but Snow White did sell twice as many tickets, 42,682 to be exact, grossing up to $2,800,435$ Belgian francs net income. It was the only screening where Capitole bothered to open a second register that year. This was a major success because this time, the Capitole did raise the price of its tickets. One of the explanations can be that this time the uncensored version was shown. In the meantime, Disney's film division was turning out box office duds in the 1970s (Wasko, 2001); in Ghent, there were no new releases, and the reruns of Peter Pan and Lady and the Tramp were not that overwhelmingly successful during the holiday season. But even so, they still made it in the top 10 of highest grossing films that year.

It is clear that the Sofexim-Cinex management had control over the Disney screenings in Ghent and used a very specific strategy for these screenings; we can conclude that 
screening Walt Disney productions at these particular times was catering to the community's taste. Disney's animated feature films were reeling in the money for Capitole; instead of following the distribution chain, they found the golden goose by making Disney's animated feature films extremely exclusive, keeping it out of the district and suburb cinemas and programming it in the Capitole at Christmas. As such, we question whether this strategy of extremely limited market release was used as a business model for success, with the examples of using Disney screenings at the opening of the acquired Rex in 1969 and at the reopening of the duplex Majestic in 1976. Another sign is that it only took Decascoop (the 1981 new multiplex in town) 1 week after the bankruptcy of the Sofexim-Cinex company to start screening One Hundred and One Dalmatians (1961). Later that year, Capitole reopened under new management, hoping to revive the old cinema structure. Yet, by that time, Decascoop had opened Christmas screenings early with the blockbuster The Aristocats, and Capitole had lost its excellent reputation and habitual image of Christmas Disney screenings at the only true film palace in town.

\section{Memory and Disney}

One of the key findings of the research on the social experience of cinema is that cinemagoing must have been less about particular films than about the experiences surrounding the activity of cinemagoing; the sociality and eventfulness of cinemagoing were important to everyday life (Van de Vijver and Biltereyst, 2013). The final part of this article attempts to understand whether these programming strategies, financial decisions and exhibition practices had any influence on how the Disney screenings were perceived and experienced at the time. To understand the social experience of going to the movies as a child, oral histories were analyzed as discourses. The rich memories of the respondents are personal memories, but they do have recurrent and pervasive sets of similarities, especially in terms of childhood memories. When asked about the first memory of movie attendance, the respondents often described their memories in great detail, underscoring the importance of the new experience and the lasting impact this had on them as young children. The memories of going to the movies were specifically socio-geographically distinct; mechanisms of social segregation were apparent in recollections of the district cinemas versus the center cinemas. Memories of childhood moviegoing are often located within the districts and the smaller neighborhood cinemas. Many of them walked to the cinemas, and these memories are topographically laid out: they take the interviewer by the hand through their neighborhood to walk them to the cinema. Age limitations were indicated by the respondents themselves; they went to the neighborhood cinemas until they were about 11 to 14 years old and were usually dropped off by a family member. When asked about frequency, the respondents affirmatively answered that they went to the movies mostly during their childhood and for most on a weekly basis. They did not need to travel far, and their parents not only approved but also encouraged it because it was cheap entertainment, and it kept the children off the streets. At least it was inexpensive with the discount most of them received due to the profession of one of their parents. Some of these respondents, for instance, came from the food service industry, where parents hung posters in the windows of their establishments. These posters contained discount coupons on the corner. But as a side note, these memories are very much circumscribed by the respondents' home residence. The district 
cinemas were their playground; it was where their parents would drop them off if they didn't like the children playing in the streets. It was usually warm and cozy, and above all familiar ground. The memories recollect a sense of community and reflect an extension of the home life in these spaces. Now, the center cinemas were different: Things were more regulated there. To go to the center cinemas, you had to be accompanied, dressed the proper way and choice of films was defined by the programming preferences of the city center cinemas' managers. For all young children, going to the movies meant having no say in the matter of the film screened; (grand)parents, whether accompanying the children or not, chose the cinema and therefore the film. As a child, cinemagoing was a common and even habitual part of everyday life. But childhood memories were not only defined by the social apparatus of the cinemas but also by what was programmed. For our respondents, who rarely remembered the films from their childhood moviegoing, it was the character names that were more consistent than the film titles. Genres were more generally remembered, such as the Westerns and gangster films that were programmed over several weeks and films with frequently returning characters such as Zorro or Tarzan. Moreover, actors such as Charlie Chaplin and Laurel and Hardy were repeatedly remembered. The programs of the center cinemas were less frequently mentioned in the recollections of childhood unless Disney was concerned.

The research on the reception of Disney products and on the proliferation of Disney globally has concluded, among many things, that Disney was viewed as essentially benign, as American with transnational possibilities and that certain core values were understood across cultures. Overall, the pervasiveness of the brand through the variety of products was clear (Wasko et al., 2001). But the memories under the research here came up under different circumstances and different research questions and melted more into the general moviegoing habits of our respondents. Our respondents were not asked about Disney, yet some clear characteristics were constantly popping up because very often, the first movie one ever saw was a Walt Disney production, most noticeably Snow White (see Figure 1). Immediately, the atmosphere of something out of the ordinary emerges from these memories because not only was the setting different, the whole event differed vastly from their childhood habitual moviegoing experiences. Additionally, most of these memories had little reference to the district or neighborhood cinema ambience. Remembering Disney screenings indicated very specific spatial descriptions of luxury and circumscribed well-mannered behavior:

I don't recall if it was the first time, the first one I remember is Bambi ... in the Rex. As far as I know. That was a surprise, visiting the cinema ... This was an occasion, something special, like Snow White! (H., 1933)

Only for a very special movie was I allowed to go to the Capitole, the most beautiful cinema in the whole world, with golden curtains: a fairytale! ... Once a year, for those Disney movies after the war. (V.A., 1936)

But when I was about five or six, I went to the center cinemas for the first time with my mother. We went to the Majestic ... We went to see Snow White. There was a very long line, and eventually it was our turn. This was so much different from the district cinemas with wooden seats. Here there were plush seats! That made a great impression. Completely different lighting 
$\ldots$ and of course the animated film. And that made a great impression, because before that, I just went along to any screening because it was nice and warm, and I usually slept more then I saw anything. (A., 1944)

The eventfulness of the Disney screenings is fortified by the remembered timing of these films. The films are remembered during the holidays, especially during Christmas time, making a visit to the cinema a special occasion. Some respondents continued the tradition with their children or grandchildren, indicating the celebratory eventfulness of the Disney screenings:

Most people stayed indoors on Christmas Day. Or a really good film was playing. It was the holidays, so there was usually an animation film ... like Bambi or Jungle Book. But otherwise, no. (B., 1932)

Yes, the real big films, the American films and the Walt Disney films. Each year with Christmas and New Year. That was our Christmas Day planning. And each year another one, of course. (V.V., 1936)

The out-of-the-ordinary visits are reinforced by very specific issues recalled that were less frequently remembered in everyday moviegoing, such as memories of non-continuous programming, the first color picture, advertisements, language issues and price issues. Again, these very specific memories lift the Disney screenings above the habitual cinemagoing:

With a lot of advertisement. For instance, the Disney films; there was much ado about that, huge announcements. Probably because they were rather expensive productions. (C., 1943)

I do remember going to the cinema as a very small child, before I was eleven, to the Capitole, to see Snow White and Cinderella, which came out in the Capitole in original versions, not in Dutch, but with subtitles. Of course as a child, you didn't understand much. But it worked! (M., 1945)

I thought about that. If I'm not mistaken, the balcony was about 12,5 francs. That was the Capitole. It was all pretty much the same price. There was also a mezzanine, which was the most expensive. Children received discounts. But not for the Disney films. Everyone had to pay the same amount then, even the children! (V., 1937)

Remembering specific movie titles is less common than the cinemagoing memories (Van de Vijver and Biltereyst, 2013). But even when movie titles were mentioned in between conversations, memories of Disney were quite resonant. Over the 62 interviews, 257 different movies were named, and a top 10 list was generated with the most-mentioned movies: Snow White ranked fourth, Bambi sixth and Cinderella ninth, indicating the importance of the memories constructed through the initial screening and the lifelong commitment to the films. Not all films were mentioned in the context of theatrical cinemagoing, as both Bambi and Snow White particularly also came up in discussing film fandom and especially video or DVD collections: 
All those films! Cinderella, Snow White, Bambi, of all those stories you could think of, Walt Disney's were the most beautiful films ... You had to have seen them; I have the best of memories. It sticks, it stays with you, and then you see them on the small screen and you say, yes, those were marvelous films. (L., 1942)

Remembering Disney screenings seemed to be about remembering an extraordinary screening or event in the center cinemas. Even the center residents' oral histories testify to an almost elitist event and less to an atmosphere of shared pleasures common to even the center cinemagoing habits. So an image of distinctiveness rather than omnipresence or accessibility emerges from these Disney screenings. The programming policies such as keeping Disney's animated feature films out of the district cinemas and programming them in a cinema which was highly socially and culturally defined not only generated income - it structured the way a popular media product for children was perceived as extraordinary and accessible when certain conditions were met with such as a higher ticket price, a Christmas visit, respectable attire and required company. This is how watching Disney was made into something special for these children in Ghent. To give another example, this would, for instance, not be the case in our capital, Brussels, where the Ambassador had a continuous programming of Disney movies in the Disney Cine.

\section{Conclusion}

Disney's animated feature films were released into the local film exhibition market of Ghent in a very particular way. The films were distributed in the 1930s and 1940s to maximize profits by distributing the film after its release to many different cinemas, which were geographically and socially diverse. Yet in the 1950s and 1960s, the film palace in town, Capitole, survived the difficult economic era of cinema among other things with the programming of Disney in the month of Christmas. This profitable combo was milked for some decades by the cinema company restricting the Disney screenings to the socially elitist aura of the Capitole. The business model was not always successfully implemented in the other major first-run cinemas by the management of the Sofexim-Cinex company, and by the time the multiplex came to town, cinemagoing habits had shifted and the rundown Capitole had lost too much of its glamor to uphold Christmas Disney screenings. The way Disney was programmed in Ghent very much structures the way Disney's animated feature films are remembered, shaping Disney's animated feature films in this local market into something exclusive, non-pervasive and out of the ordinary of everyday life cinemagoing. It is clear that for this particular market, the scarcity of the Disney feature films made them not only into an extraordinary and celebratory event but also into a non-inclusive memory of elitist cinemagoing. The memories speak less of a familiarity with the often quoted Disney family fun, happiness and pleasure and more of socially circumscribed awe and de-ritualized cinemagoing habits. The relevance of this research based on cross-referenced datasets on local cinema history in Ghent is the ability to value localism from a bottom-up approach to contest top-down (and often Anglo-Saxon) assumptions about the conditions of spending leisure time and popular child culture. Evidence of popularity from financial data and evidence of reception from oral histories that conventional accounts of Disney's ubiquity in historical 
popular culture and its accessibility to all children of all classes is not confirmed by this detailed analysis of how the animated feature films were made available to audiences in Ghent. This local, fine-tuned understanding of the reception of Disney products can be a methodological and exemplary illustration of how empirical, qualitative audience research into everyday leisure time can nuance the canonized common knowledge of popular film or entertainment media.

\section{Funding}

This research received no specific grant from any funding agency in the public, commercial or not-for-profit sectors.

\section{Notes}

1. The time period under research is defined by the subject; the research started in 1937, the year of the production of the first feature-length film of Walt Disney Productions, Snow White and the Seven Dwarfs (Walt Disney Productions; US, 1937). The analysis concludes in 1982 with the almost entire demise of the traditional cinema structure in Ghent due to the introduction of the newly built multiplex cinema in town; as such, the analysis is contained to the era of the one-screen cinema. The 24 films under research were Snow White and the Seven Dwarfs (Walt Disney Productions; US, 1937), Fantasia (Walt Disney Productions; US, 1940), Pinocchio (Walt Disney Productions; US, 1940), Dumbo (Walt Disney Productions; US, 1941), Bambi (Walt Disney Productions; US, 1942), Saludos Amigos (Walt Disney Productions; US, 1942), The Three Caballeros (Walt Disney Pictures and Walt Disney Productions; US, 1944), Make Mine Music (Walt Disney Productions; US, 1946), Fun and Fancy Free (Walt Disney Productions; US, 1947), Melody Time (Walt Disney Productions; US, 1948), Adventures of Ichabod and Mr. Toad (Walt Disney Productions; US, 1949), Cinderella (Walt Disney Productions; US, 1950), Alice in Wonderland (Walt Disney Productions; US, 1951), Peter Pan (Walt Disney Productions; US, 1953), Lady and the Tramp (Walt Disney Productions; US, 1955), Sleeping Beauty (Walt Disney Productions; US, 1959), One Hundred and One Dalmatians (Walt Disney Productions; US, 1961), The Sword in the Stone (Walt Disney Productions; US, 1963), The Jungle Book (Walt Disney Productions; US, 1967), The Aristocats (Walt Disney Productions; US, 1970), Robin Hood (Walt Disney Productions; US, 1973), The Many Adventures of Winnie the Pooh (Walt Disney Productions; US, 1977), The Rescuers (Walt Disney Productions; US, 1977) and The Fox and the Hound (Walt Disney Productions; US, 1981).

2. In 1930, Ghent had a population of 170,358 inhabitants, and there were 29 active cinemas and 18,601 seats; in 1960, Ghent had a population of 159,056 inhabitants with 39 active cinemas and with an average of 22 cinema visits per year per person. In 1977, the borders of the city were redefined to include the border municipalities; by 1980, Ghent had a population of 239,959 inhabitants but with only 17 active cinemas and an average of only four visits per year per person. When the final traditional one-screen center cinema closed in 1985, Ghent had 234,251 inhabitants, 5 active cinemas and 6803 seats. Source: Belgian Federal Public Service Economy.

\section{References}

Allen RC (2006) Relocating American film history. The 'Problem' of the empirical. Cultural Studies 20(1): 48-88.

Allen RC (2011) Reimagining the history of the experience of cinema. In: Maltby R, Biltereyst $\mathrm{D}$ and Meers P (eds) Explorations in New Cinema History: Approaches and Case Studies. Oxford: Blackwell, pp.41-57. 
Aveyard K and Moran A (eds) (2013) Watching Films: New Perspectives on Movie-Going, Exhibition and Reception. Bristol: Intellect Books.

Ayres B (2013) The Emperor's Old Groove: Decolonizing Disney's Magic Kingdom. New York: Peter Lang.

Barrier M (2007) The Animated Man: A Life of Walt Disney. Berkeley, CA: University of California Press.

Bell E, Haas L and Sells L (eds) (1995) From Mouse to Mermaid: The Politics of Film, Gender, and Culture. Bloomington, IN: Indiana University Press.

Biltereyst D, Meers P and Van de Vijver L (2011) Social class, experiences of distinction and cinema in postwar Ghent. In: Maltby R, Biltereyst D and Meers P (eds) Explorations in New Cinema History: Approaches and Case Studies. Oxford: Blackwell, pp.101-124.

Biltereyst D and Meers P (2014) Mapping film exhibition in Flanders (1920-1990). A diachronic analysis of cinema culture combined with demographic and geographic data. In: Hallam J and Roberts L (eds) New Spatial Methodologies in Cinema and the Moving Image. Bloomington, IN: Indiana University Press, pp.80-105.

Bowles K (2007) 'Three miles of rough dirt road': Towards an audience-centred approach to cinema studies in Australia. Studies in Australasian Cinema 1(3): 245-260.

Brode D (2004) From Walt to Woodstock: How Disney Created the Counterculture. Austin, TX: University of Texas Press.

Buckingham D (1997) Dissin' Disney: Critical perspectives on children's media culture. Media, Culture \& Society 19(2): 285-293.

Chapman J, Glancy M and Harper S (eds) (2007) The New Film History: Sources, Methods, Approaches. Basingstoke: Palgrave Macmillan.

Christie I (2006) 'Just the facts, m'am?' A short history of ambivalence towards empiricism in cinema studies. Tijdschrift voor Mediageschiedenis 9(2): 65-73.

Crafton D (2013) Shadow of a Mouse: Performance, Belief, and World-Making in Animation. Berkeley, CA: University of California Press.

Davis AM (2006) Good Girls and Wicked Witches: Women in Disney's Feature Animation. Eastleigh: John Libbey Publishing.

Dorfman A and Mattelart A (1975) How to Read Donald Duck: Imperialist Ideology in the Disney Comic. New York: International General.

Elsaesser T (2014) What might we mean by media history? (1994). Tijdschrift voor Mediageschiedenis 17(1): 75-82.

Field R (1942) The Art of Walt Disney. New York: Macmillan.

Ginzberg C (1993) Microhistory: Two or three things that I know about it. Critical Inquiry 20(1): $10-35$.

Giroux HA and Pollock G (2001) The Mouse That Roared: Disney and the End of Innocence. Lanham, MD: Rowman \& Littlefield.

Higashi S (2004) In focus: Film history, or a Baedeker guide to the historical turn. Cinema Journal 44(1): 94-100.

Jenkins H (ed.) (1998) The Children's Culture Reader. New York: New York University Press.

Kuhn A (2010) Snow White in 1930s Britain. Journal of British Cinema and Television 7(2): $183-199$.

Maltby R, Biltereyst D and Meers P (eds) (2011) Explorations in New Cinema History: Approaches and Case Studies. Oxford: Wiley-Blackwell.

Maltby R, Stokes M and Allen RC (eds) (2007) Going to the Movies: Hollywood and the Social Experience of Cinema. Exeter: University of Exeter Press.

Ohmer S (1993) 'That rags to riches stuff': Disney's Cinderella and the cultural space of animation. Film History 5(2): 231-249. 
Perks R and Thomson A (eds) (2000) The Oral History Reader. London: Routledge.

Phillips M (2001) The global Disney audiences project: Disney across cultures. In: Wasko J, Phillips M and Meehan ER (eds) Dazzled by Disney: The Global Disney Audiences Project. London: Leicester University Press, pp.31-61.

Ray RB (1985) A Certain Tendency of the Hollywood Cinema, 1930-1980. Princeton, NJ: Princeton University Press.

Rothschild S (2013) The Princess Story: Modeling the Feminine in Twentieth-Century American Fiction and Film. New York: Peter Lang.

Sammond N (2005) Babes in Tomorrowland: Walt Disney and the Making of the American Child, 1930-1960. Durham, NC: Duke University Press.

Smoodin E (1994) Disney Discourse: Producing the Magic Kingdom. New York: Routledge.

Smoodin E (2012) Snow White and the Seven Dwarfs. London: Palgrave Macmillan.

Stein A (2011) Why We Love Disney: The Power of the Disney Brand. New York: Peter Lang.

Van de Vijver L and Biltereyst D (2010) Hollywood versus lokaliteit. Het (on)gelijke aanbod van Amerikaanse en Europese film in de jaren dertig in Gent. Tijdschrift voor Mediageschiedenis 13(2): 60-79.

Van de Vijver L (2012) Distributie en exploitatie van film te Gent. Een historische typologie op basis van de programmeringsprofielen. Tijdschrift voor Sociale en Economische Geschiedenis 9(2): 73-100.

Van de Vijver L and Biltereyst D (2013) Cinemagoing as a conditional part of everyday life. Memories of cinemagoing in Ghent from the 1930s to the 1970s. Cultural Studies 27(4): 561-584.

Van de Vijver L, Biltereyst D and Velders K (2015) Crisis at the Capitole: A cultural economics analysis of a major first run cinema in Ghent, 1953-1971. Historical Journal of Film, Radio and Television 35(1): 75-124.

Wasko J (2001) Understanding Disney: The Manufacture of Fantasy. Cambridge: Polity.

Wasko J, Phillips M and Meehan E (eds) (2001) Dazzled by Disney: The Global Disney Audiences Project. London: Leicester University Press.

\section{Biographical note}

Lies Van de Vijver is a visiting professor of Film Historiography and a post-doctoral researcher at the Centre for Cinema and Media Studies (Ghent University), working on various research projects on the history of screen culture, film programming and cinema experience. She is coordinator of the History of Moviegoing, Exhibition and Reception (HoMER) Network and the Digital Cinema Studies (DICIS) Network, and frequently co-organizes conferences on media history research. She has published in several international journals and readers, and is currently working on the social history of the multiplex. 